\title{
Balanced pan-PPAR activator bezafibrate in combination with statin: comprehensive lipids control and diabetes prevention?
}

\author{
Alexander Tenenbaum ${ }^{1,2,3^{*}}$ and Enrique Z Fisman ${ }^{2,3}$
}

\begin{abstract}
All fibrates are peroxisome proliferators-activated receptors (PPARs)-alpha agonists with ability to decrease triglyceride and increase high density lipoprotein- cholesterol (HDL-C). However, bezafibrate has a unique characteristic profile of action since it activates all three PPAR subtypes (alpha, gamma and delta) at comparable doses. Therefore, bezafibrate operates as a pan-agonist for all three PPAR isoforms. Selective PPAR gamma agonists (thiazolidinediones) are used to treat type 2 diabetes mellitus (T2DM). They improve insulin sensitivity by up-regulating adipogenesis, decreasing free fatty acid levels, and reversing insulin resistance. However, selective PPAR gamma agonists also cause water retention, weight gain, peripheral edema, and congestive heart failure. The expression of PPAR beta/ delta in essentially all cell types and tissues (ubiquitous presence) suggests its potential fundamental role in cellular biology. PPAR beta/ delta effects correlated with enhancement of fatty acid oxidation, energy consumption and adaptive thermogenesis. Together, these data implicate PPAR beta/delta in fuel combustion and suggest that pan-PPAR agonists that include a component of PPAR beta/delta activation might offset some of the weight gain issues seen with selective PPAR gamma agonists, as was demonstrated by bezafibrate studies. Suggestively, on the whole body level all PPARs acting as one orchestra and balanced pan-PPAR activation seems as an especially attractive pharmacological goal. Conceptually, combined PPAR gamma and alpha action can target simultaneously insulin resistance and atherogenic dyslipidemia, whereas PPAR beta/ delta properties may prevent the development of overweight. Bezafibrate, as all fibrates, significantly reduced plasma triglycerides and increased HDL-C level (but considerably stronger than other major fibrates). Bezafibrate significantly decreased prevalence of small, dense low density lipoproteins particles, remnants, induced atherosclerotic plaque regression in thoracic and abdominal aorta and improved endothelial function. In addition, bezafibrate has important fibrinogen-related properties and anti-inflammatory effects. In clinical trials bezafibrate was highly effective for cardiovascular risk reduction in patients with metabolic syndrome and atherogenic dyslipidemia. The principal differences between bezafibrate and other fibrates are related to effects on glucose level and insulin resistance. Bezafibrate decreases blood glucose level, $\mathrm{HbA1C}$, insulin resistance and reduces the incidence of T2DM compared to placebo or other fibrates. Currently statins are the cornerstone of the treatment and prevention of cardiovascular diseases related to atherosclerosis. However, despite the increasing use of statins as monotherapy for low density lipoprotein- cholesterol (LDL-C) reduction, a significant residual cardiovascular risk is still presented in patients with atherogenic dyslipidemia and insulin resistance, which is typical for T2DM and metabolic syndrome. Recently, concerns were raised regarding the development of diabetes in statin-treated patients. Combined bezafibrate/statin therapy is more effective in achieving a comprehensive lipid control and (Continued on next page)
\end{abstract}

\footnotetext{
* Correspondence: altenen@post.tau.ac.il

${ }^{1}$ Cardiac Rehabilitation Institute, Sheba Medical Center, 52621, Tel-Hashomer, Israel

${ }^{2}$ Sackler Faculty of Medicine, Tel-Aviv University, 69978, Tel-Aviv, Israel

Full list of author information is available at the end of the article
}

\section{Biomed Central}

(c) 2012 Tenenbaum and Fisman; licensee BioMed Central Ltd. This is an Open Access article distributed under the terms of the Creative Commons Attribution License (http://creativecommons.org/licenses/by/2.0), which permits unrestricted use, distribution, and reproduction in any medium, provided the original work is properly cited. 
(Continued from previous page)

residual cardiovascular risk reduction. Based on the beneficial effects of pan-PPAR agonist bezafibrate on glucose metabolism and prevention of new-onset diabetes, one could expect a neutralization of the adverse pro-diabetic effect of statins using the strategy of a combined statin/fibrate therapy.

Keywords: Atherogenic dyslipidemia, Bezafibrate, Combined fibrate/statin therapy, Metabolic syndrome, PPAR, Prevention, Residual cardiovascular risk, Type 2 diabetes

\section{Concept of the balanced pharmacological pan-PPAR activation}

All fibrates are peroxisome proliferators-activated receptors (PPARs)-alpha agonists with ability to decrease triglyceride and increase high density lipoprotein- cholesterol (HDL-C). However, bezafibrate, in comparison with other fibrates has a unique characteristic profile of action since it activates all three PPAR subtypes (alpha, gamma and delta) at comparable doses [1-5]. Therefore, bezafibrate operates as a pan-agonist for all three PPAR isoforms (Figure 1). Paradoxically, bezafibrate was serendipitously developed before the discovery of PPARs, but till now is the only clinically available pan-PPAR balanced ligand. What is the main distinctiveness of the PPARs from a clinical point of view?

PPAR alpha, activated by polyunsaturated fatty acids and fibrates, is implicated in the regulation of lipid metabolism, lipoprotein synthesis and metabolism, as well as inflammatory response in liver and other tissues. PPAR alpha plays a crucial role in regulating the $\beta$-oxidation of fatty acids, a major source of cellular energy. Consistent with this, PPAR alpha is highly expressed in tissues with high fatty acid oxidation (like liver, kidney and heart muscle), in which it controls a comprehensive set of genes that regulate most aspects of lipid catabolism. PPAR alpha activation increase HDL-C synthesis, stimulates "reverse" cholesterol transport and reduces triglycerides [6-8].

PPAR gamma regulates adipogenesis, lipid metabolism, glucose control, and inflammation/vascular pathways. Clinically, selective PPAR gamma agonists like thiazolidinediones (glitazones) are used to treat type 2 diabetes mellitus (T2DM). They improve insulin sensitivity by up-regulating adipogenesis, decreasing free fatty acid levels, and reversing insulin resistance. However, selective PPAR gamma agonists also cause water retention, weight gain, peripheral edema, and congestive heart failure. Such adverse effects may contribute to controversial cardiovascular outcomes despite apparent improvements in other risk factors $[2,7,9,10]$.

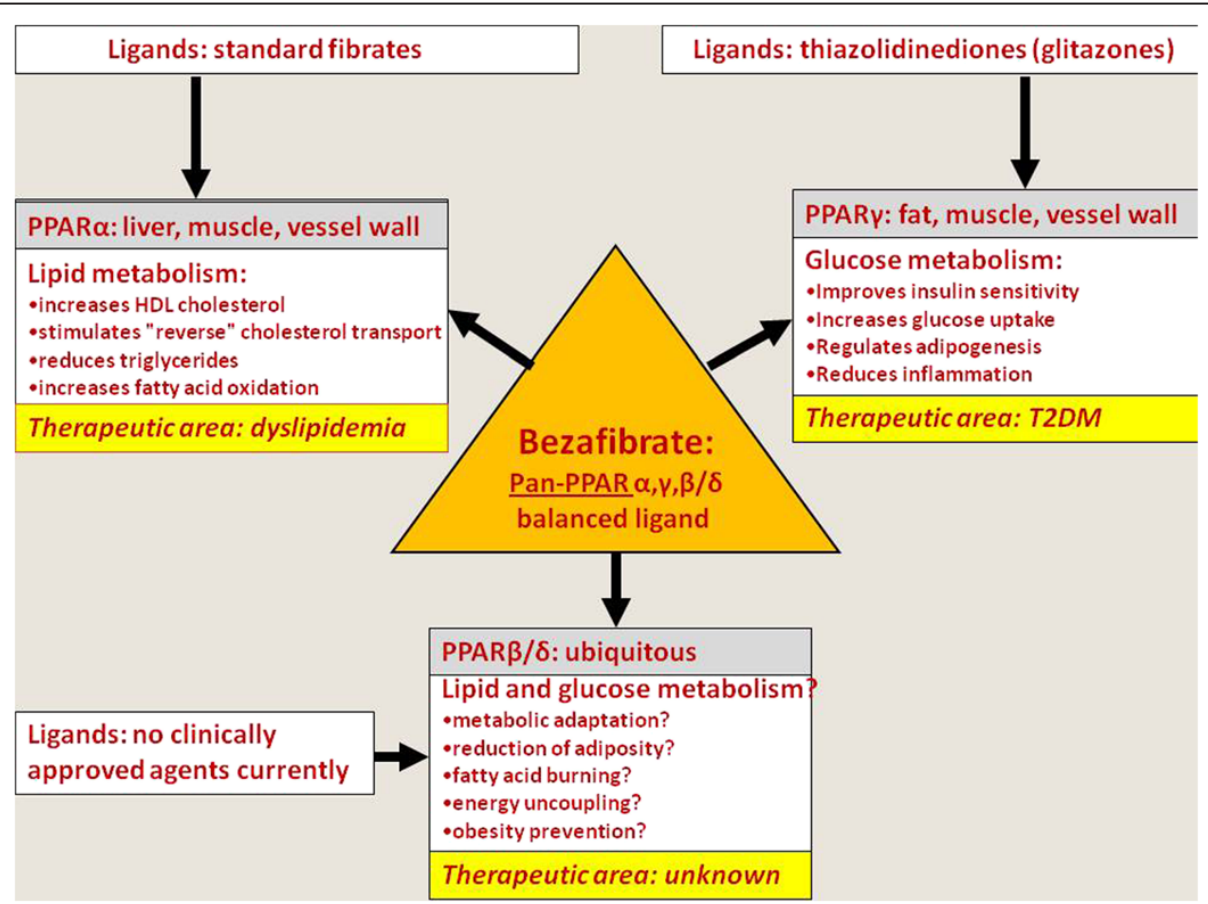

Figure 1 Bezafibrate activates all three PPAR subtypes (alpha, gamma and delta) at comparable doses and operates as a balanced pan-PPAR ligand. 
Although PPAR beta/ delta agonists are not currently in clinical use (besides as a part of bezafibrate effects), their role in the whole body level seems very important. The expression of PPAR beta/delta in essentially all cell types and tissues (ubiquitous presence) suggests its potential fundamental role in cellular biology and possible widespread effects of its agonists [11,12]. Particularly, selective overexpression of a constitutively active form of PPAR beta/delta in mouse adipose tissue induces significant weight loss and protects against the obesity and dyslipidemia induced by a high-fat diet [13]. This PPAR beta/ delta effect correlated with enhancement of fatty acid oxidation, energy consumption and adaptive thermogenesis. This change may explain why mice that overexpress PPAR beta/ delta in skeletal muscle can run twice the distance of control mice [14]. Together, these data implicate these PPAR in fuel combustion and suggest that pan-PPAR agonists that include a component of PPAR beta/delta activation might offset some of the weight gain issues seen with selective PPAR gamma agonists [15], as was demonstrated in bezafibrate studies [16].

The PPARs alpha and gamma are therapeutic targets for hypertriglyceridemia and insulin resistance, respectively. Evidence is now emerging that the PPARbeta/delta isotype is a potential pharmacological target for the treatment of disorders associated with metabolic syndrome. PPAR beta/delta activation increases lipid catabolism, improves the serum lipid profile and insulin sensitivity in several animal models. In addition, PPAR beta/delta ligands prevent weight gain and suppress macrophage-derived inflammation. These data are promising and indicate that PPAR beta/delta ligands may become a therapeutic option for the treatment of metabolic syndrome $[17,18]$.

Suggestively, on the whole body level all PPARs acting as one orchestra and balanced pan-PPAR activation seems as an especially attractive pharmacological goal. Conceptually, we were the first who proposed an idea of pan-PPAR activation: combined PPAR gamma and alpha action can target simultaneously insulin resistance and atherogenic dyslipidemia [2,6], whereas PPAR beta/delta properties may prevent the development of overweight which typically accompanies selective PPAR gamma ligands.

\section{Balanced pan-PPAR activator bezafibrate: effects in patients with atherogenic dyslipidemia and metabolic syndrome}

Hence, what data have we while looking on pan-PPAR balanced activator bezafibrate? As all fibrates (PPAR alpha activators), it significantly reduced plasma triglycerides and increased HDL-C level (considerably stronger than other major fibrates) [19-21]. Bezafibrate significantly decreased the prevalence of small, dense LDL particles, remnants [22] and induced atherosclerotic plaque regression in thoracic and abdominal aortas [23]. In addition, bezafibrate has important fibrinogen-related properties and anti-inflammatory effects. It is well established that fibrinogen is an independent predictor of cardiovascular events in patients with coronary artery disease [24]. Bezafibrate treatment lowers fibrinogen concentrations and reduces other markers of systemic inflammation (like tumor necrosis factor (TNF)-alpha and interleukin (IL)-6 and C-reactive protein) [25-27]. As a result, endothelial function was improved by bezafibrate [28-30] but probably in a less extend than by high dose atorvastatin [31].

In clinical trials bezafibrate, as all fibrates, was highly effective in patients with atherogenic dyslipidemia (presented by low HDL-C and increased triglycerides). In patients without dyslipidemia this favorable effect was absent and the same event rate was observed in both bezafibrate and placebo groups. Consequently, the main determinant for the overall results of the trial was mainly dependent on the number of the appropriately included patients [19]. For example, in the Bezafibrate Infarction Prvention (BIP) study about $50 \%$ of patients did not need fibrates at all. In addition, significantly more patients from the placebo group were "under covered" treated with statins (it was a violation of the study protocol). As a result, after a mean 6.2 year follow-up bezafibrate effect did not reach significance in the overall population $(9.4 \%$ risk reduction, $\mathrm{p}=0.24)$. However, in appropriate patients with atherogenic dyslipidemia bezafibrate lead to $42 \%$ risk reduction $(\mathrm{p}=0.02)$ [19,20]. Furthermore, after a mean 8.2 year follow-up bezafibrate benefit was significant even in the overall population ( $17 \%$ risk reduction, $\mathrm{p}=0.03$ ) [32].

There are few direct "head to head" statin vs. bezafibrate comparisons in terms of cardiovascular outcomes. Intermediate-size (274 patients) randomized controlled trials have demonstrated that bezafibrate was significantly better than pravastatin (a relatively weak statin) in reduction of cardiovascular events [33].

Because pan-PPAR modulation is a key event in the development of the metabolic syndrome [34], it was of special interest to evaluate bezafibrate effects in this syndrome. In patients with metabolic syndrome, bezafibrate treatment was associated with a significant (29\%) reduced risk of any myocardial infarction (MI) and 33\% reduced risk of non-fatal MI. The early decrease in MI incidence was reflected later in a tendency to reduced cardiac mortality. Of note, among patients with augmented features of metabolic syndrome (4-5 risk factors for metabolic syndrome) a marked 56\% reduction in cardiac mortality on bezafibrate was observed [16].

Figure 2 illustrates meta-analysis of all available 4 randomized control trials with bezafibrate (about 5000 


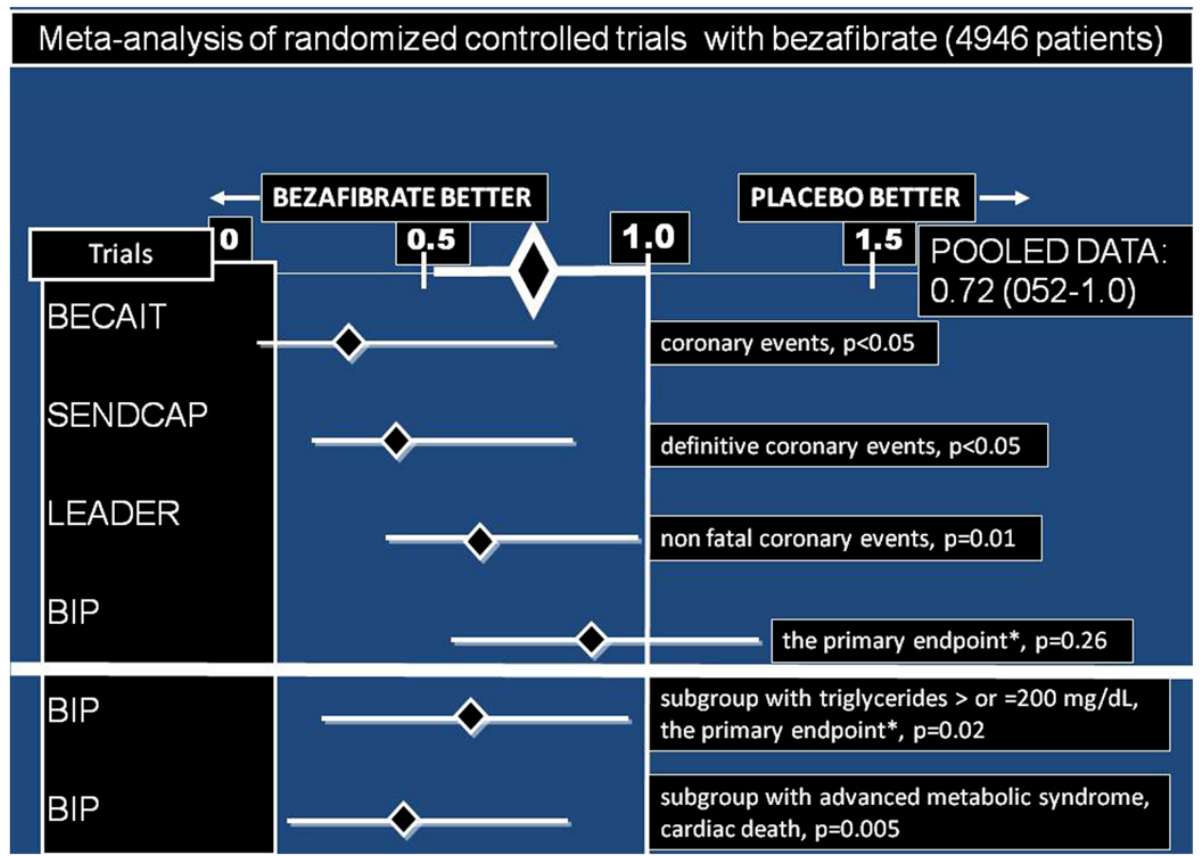

Figure 2 Meta-analysis of all available 4 randomized control trials with bezafibrate $[20,21,35,36]$ in "overall populations" (4946 patients), based in part on the comprehensive meta-analysis of Jun and colleagues [37]: $28 \%$ coronary events risk reduction was observed (relative risk $\mathbf{0 . 7 2 2}$, confidence interval $\mathbf{0 . 5 1 8 - 1 . 0 0 5 ) . ~ T h i s ~ e f f e c t ~ w a s ~ s i g n i f i c a n t l y ~ a u g m e n t e d ~ ( s h o w n ~ b e l o w ~ t h e ~ b o l d ~ w h i t e ~ l i n e ) ~ i n ~}$ the subgroups of appropriate patients with metabolic syndrome and dyslipidemia [19,20].

patients) in "overall populations" [20,21,35,36], based in part on the comprehensive meta-analysis of Jun and colleagues [37]: 28\% coronary events risk reduction was observed. As mentioned above, this effect was significantly augmented in appropriate patients with metabolic syndrome and dyslipidemia $[19,20]$.

\section{Balanced pan-PPAR activator bezafibrate: effects on glucose metabolism and prevention of T2DM}

The principal differences between bezafibrate and other fibrates are related to its effects on glucose level and insulin resistance. A large number of studies showed beneficial effects of bezafibrate on glucose and insulin metabolism [25,38-46]. These effects could be primarily related to the direct influence of bezafibrate on insulin sensitivity via PPAR gamma. However, additional PPAR alpha - mediated effects on lipids metabolism may be also important.

Hyperlipidemia, free fatty acids (FFAs) overload and lipid accumulation in non-adipose tissues influence both insulin action and insulin secretion and are frequently associated with insulin resistance and the development of T2DM [47-52]. We have previously shown that insulin resistance is significantly correlated with triglycerides level. Triglyceride-lowering and HDL-C-raising effects of bezafibrate lead to decreased systemic availability of fatty acids, diminished fatty acid uptake by muscle with improvement of insulin sensitization, contributing also to a reduction of plasma glucose levels $[40,42]$. However the role of FFAs extends beyond their ability to induce or exacerbate insulin resistance and inflammation: they may contribute directly to the deterioration of beta cell function that accompanies the development of diabetes [53-56]. Lipotoxicity and glucotoxicity share many common features, and FFAs and glucose metabolism are intimately linked through their ability to act as competing oxidative substrates [48]. Probably, reducing the chronic secretory demands for pancreatic beta-cell by improving insulin sensitivity and direct reducing of triglycerides and FFA accumulation in pancreatic islets can explain preservation of beta cell function in patients with T2DM treated with bezafibrate.

Bezafibrate has a modest but significant beneficial effect on HbA1C $[41,43]$. For example, in the recent large Japanese the J-BENEFIT study HbA1c decreased significantly by about $-0.8 \%$ [43]. This effect was observed irrespective of diabetes drug administration, but with a strong positive relationship between triglyceride and $\mathrm{HbA1c}$ reduction. In the BIP, bezafibrate reduces the incidence and delays the onset of T2DM vs. placebo among different high-risk populations: patients with impaired fasting glucose (30\% reduction) [44] and obese patients even with normal fasting glucose levels (42\% reduction) [45]. A strong independent support for BIP was found in a large British study of 16352 fibrate users during 5-year follow-up: 12161 of patients used bezafibrate and 4191 of 
patients used other fibrates [46]. Bezafibrate was associated with reduced hazard for diabetes of $41 \%$; hazard for progression to use of antidiabetic medication was by $46 \%$ less and progression to insulin by $22 \%$ less in patients with bezafibrate.

In contrast to patients treated with selective PPAR gamma activators, there was no significant change in mean body mass index (BMI) values in the bezafibrate treated patients during the follow-up [19]. Probably, prevention of weight gain could be explained by the PPAR beta/delta mediated effects of bezafibrate. In addition, bezafibrate significantly increased adiponectin levels both in humans and rodents. This effect was mediated mostly via PPAR alpha, but also partially via PPAR gamma [57]. Therefore, a pharmacological intervention that simultaneosly influences lipids and glucose metabolism can be particularly effective to reduce the incidence and delay the onset of T2DM in appropriate high risk patients. These data support our suggestion that on the whole body level a balanced synergism of all PPARs could be justified.

\section{Bezafibrate in combination with statin: current concepts, evidences and suggestions}

Currently statins are the cornerstone of the treatment and prevention of cardiovascular diseases related to atherosclerosis [58-60]. However, despite the increasing use of statins as monotherapy for LDL-C reduction, a significant residual cardiovascular risk is still present in patients with atherogenic dyslipidemia and insulin resistance which is typical for T2DM and metabolic syndrome [61-71]. The risk associated with high triglycerides and low HDL may be eliminated by bezafibrate. Among major fibrates, bezafibrate appears to have the strongest $[42,47]$ effect on HDL-C.

Intensive statin therapy increases the possibility of side effects (elevations of liver enzymes, muscle aches and cognitive decline). Recently, concerns raised regarding the development of diabetes in statin-treated patients. Multiple studies showed that most popular statins - simvastatin, atorvastatin, and rosuvastatin - have deleterious effects on glycemic control [72-83]. For example, in the CORONA trial [77], statin users were at a 1.13-fold (95\% CI, 0.86-1.50) greater risk of developing new-onset diabetes than patients taking placebo. In the JUPITER trial [78], the relative risk was even higher $(1.25$ [95\% CI, 1.05-1.49]). In the SPARCL (Stroke Prevention by Aggressive Reduction in Cholesterol Levels) trial [81], newonset T2DM developed in 166 of 1,905 patients randomized to atorvastatin $80 \mathrm{mg} /$ day and in 115 of 1,898 patients in the placebo group $(8.71 \%$ vs. $6.06 \%$, adjusted HR: $1.37,95 \%$ CI: 1.08 to $1.75, p=0.011)$. It should be pointed out that a newest statin - pitavastatin - seems to be better in this issue in the post-hoc LIVES study sub-analysis [84]. Still, the cardiovascular benefits of statin therapy clearly outweigh the risk of developing diabetes $[60,82]$. However, the data suggest the need to make patients aware of this possible risk and to monitor patients for eventual development of diabetes, especially on intensive-dose therapy. In addition, concerns regarding new-onset diabetes should not be neglected due to the serious economic burden which this condition presents now.

Of course, the importance of the intensive lifestyle changes (diet, weight reduction and physical activity) should be emphasized irrespective from the pharmacological interventions. However, as compared with statin monotherapy (effective mainly on LDL-C levels and plaque stabilization), the association of a statin with bezafibrate will also have a major impact on triglycerides, HDL and LDL particle size [20,22,58,85]. Moreover, based on the beneficial effects of pan-PPAR agonist bezafibrate on glucose metabolism and prevention of new-onset diabetes (about $30-40 \%$ risk reduction), one could expect neutralizing of the adverse pro-diabetic effect of statins (up to $25 \%$ increased risk). Therefore, a combined bezafibrate/statin therapy will be more effective in achieving a comprehensive lipid control, residual cardiovascular risk reduction and theoretically could prevent statin induced new-onset diabetes.

Though muscle pain and myositis is an issue in statin/ fibrate treatment, adverse interaction appears to occur to a significantly greater extent when gemfibrozil is administered. Bezafibrate seems to be safer and better tolerated [86-96]. Particularly, plasma concentration of statins are markedly increased by gemfibrozil but not by bezafibrate [92]. However, safety concerns about gemfibrozil may lead to unjustified precautions regarding bezafibrate administration and therefore diminish the use of this useful agent.

The Multicentre double-blind The Fluvastatin Alone and in Combination Treatment (FACT) study examined the effects on plasma lipids and safety of a combination of fluvastatin and bezafibrate during 24 weeks in 333 patients with coronary artery disease and mixed hyperlipidaemia [95]. Bezafibrate alone and fluvastatin+ bezafibrate combinations resulted in greater increases in HDL-C and decreases in triglycerides compared with fluvastatin alone $(\mathrm{P}<0.001)$. Fluvastatin $(40 \mathrm{mg})+$ bezafibrate was the most effective for all lipid parameters with a decrease from baseline at endpoint in LDL-C of $24 \%$, a decrease in triglycerides of $38 \%$ and an increase in HDL-C of $22 \%$. All treatments were well tolerated with no increase in adverse events for bezafibrate-based combination therapy versus monotherapy. No clinically relevant liver (aspartate aminotransferase [ASAT] or alanine aminotransferase [ALAT]) greater than three times the upper limit of normal) or muscular (creatine phosphokinase 
(CPK) greater than four times the upper limit of normal) laboratory abnormalities were reported.

The pooling data from 10 studies that included 1,018 patients treated with a combination of fluvastatin with fibrate (bezafibrate 493 patients, fenofibrate 158 patients, or gemfibrozil - 367 patients), have suggested that bezafibrate is the relatively safer fibrate for combination treatment [96]. For these patients, the mean (very high) dose of fluvastatin was $56 \mathrm{mg}$. The mean exposure was 38 weeks. Two patients $(0.2 \%)$ treated with the combined fluvastatin-fibrate therapy had a creatine kinase level 10 times the upper limit of normal. One patient was on a combination of fluvastatin $80 \mathrm{mg}+$ gemfibrozil $1,200 \mathrm{mg}$, and the other patient was on fluvastatin $20 \mathrm{mg}+$ fenofibrate $200 \mathrm{mg}$. Bezafibrate, which was used 3 times more than fenofibrate, was harmless in this analysis.

The safety and efficacy of combined bezafibratesimvastatin therapy was evaluated in 49 patients with diet-resistant mixed hyperlipidaemia [93]. After a twomonth placebo phase, patients were randomized to receive either Bezafibrate Slow Release (SR) $400 \mathrm{mg}$ or simvastatin $20 \mathrm{mg}$ followed by three months of combination therapy. Compared with simvastatin monotherapy, the combined therapy induced further reductions in triglycerides (by 26\%, p = 0.0003) and apoB (by $11 \mathrm{mg} / \mathrm{dl}$, $\mathrm{p}=0.03$ ) and an increase in apoA1 (by $21 \mathrm{mg} / \mathrm{dl}$, $\mathrm{p}=0.0008)$. Symptomatic and biochemical adverse events did not occur more frequently on combined drug therapy than on monotherapy. The combination of bezafibrate and simvastatin was more effective in controlling mixed hyperlipidaemia than either drug alone and did not provoke more adverse events. Despite of the strong theoretical background, there are few hard outcome data regarding combined bezafibrate and statin treatment: only one small randomized, controlled clinical trial and a number of the observational studies. Gavish et al. [94] studied the efficacy and safety of bezafibrate and simvastatin combination therapy for diabetic dyslipidaemia. All patients (148) were on single medication for a period of 6 months (100 on simvastatin $20 \mathrm{mg}$ day and 48 on bezafibrate SR $400 \mathrm{mg}$ day), followed by a period of 12 months on combined therapy for all. The simvastatin and bezafibrate combination was found to be more efficacious than a single medication for treatment of diabetic dyslipidemia, as evidenced by improvement in the lipoprotein profile, reductions in $\mathrm{Lp}(\mathrm{a})$ and fibrinogen, and almost no clinically significant side-effects. Side-effects included two patients who developed myopathy when on the combined regimen and one on the single statin regimen. Plasma creatinine phosphokinase (CPK) levels increased (but remained within the normal range) in most of the patients on combination therapy. Most of the cardiovascular events occurred within the first 6 months of the study, whilst the patients were on a single drug (12 events, 8.1\%). There was a significant reduction in the event rate during the year whilst the patients were on the combination therapy (only two events $-1.4 \%$ ).

Recently, new data regarding statin/fibrate combination were published using the high quality comprehensive nationwide Acute Coronary Syndrome Israeli Surveys (ACSIS) registry [97]. There were 8545 patients treated with statin alone and 437 patients treated with a statin/ fibrate combination (mainly bezafibrate). Development of 30-day major acute coronary event (MACE) - primary end-point - was recorded in $6.0 \%$ patients from the statin monotherapy group vs. $3.2 \%$ from the combination group, $(\mathrm{p}=0.01)$. The 30 -day re-hospitalization rate was also significantly lower in the combination group. Kaplan-Meier analysis of total mortality during one year was close to significance in favor of the combination $(p=0.066)$. Multivariate analysis identified the fibrate/statin combination as an independent predictor of $46 \%$ reduced risk of MACE in overall population ( $\mathrm{p}=0.03)$.

Madrid-Miller et al. in a small randomized controlled trial [26] investigated the impact of the addition of bezafibrate to statin treatment in 50 patients with hyperfibrinogenemia and ST-elevation acute MI. Patients were randomized into two groups (25 patients in each): bezafibrate $400 \mathrm{mg}$ (group I) and conventional therapy (group II). All patients were treated with statins. Primary endpoint was decrease of fibrinogen concentrations. Secondary endpoints were recurrence of angina or infarction, left ventricular failure and combined end points during hospitalization. Fibrinogen concentrations were lower at hospital discharge in group I than in group II (532.42 \pm 129.6 vs. $889 \pm 127.32 \mathrm{mg} / \mathrm{dl}$ in group II, p <0.0001). Secondary endpoints were more frequent in group II than in group I: angina (56\% vs. $4 \%$, RR 0.071 [0.010-0.503], p $<0.0001)$, left ventricular failure $(24 \%$ vs. $4 \%$, RR 0.167 [0.022-1.286], $\mathrm{p}=0.049)$ and combined endpoints $(76 \%$ vs. $8 \%$, RR 0.105 [0.027-0.405], p <0.001). Therefore, bezafibrate/statin treatment was a safe and was associated with a lower incidence of MACE compared with statins alone. Although in clinical trials the rate of adverse events on combination was not significantly greater compared with monotherapy, clinical and laboratory monitoring of patients who receive combined treatment should be recommended.

\section{Conclusions}

The balanced pan-PPAR activator bezafibrate simultaneously targets atherogenic dyslipidemia and insulin resistance without development of overweight; it reduces plasma triglycerides and glucose levels, increases HDL-C and decreases the prevalence of small, dense LDL particles. As a result of its concomitant effects on lipid and glucose metabolism, bezafibrate reduces the incidence and delays the onset of T2DM in high risk patients. In patients with atherogenic dyslipidemia and/or metabolic 
syndrome bezafibrate is consistently associated with a reduced risk of cardiovascular events. Combined bezafibrate/statin therapy is more effective in achieving a comprehensive lipid control and residual cardiovascular risk reduction. Based on the beneficial effects of this panPPAR agonist on glucose metabolism and prevention of new-onset diabetes, a neutralization of the adverse prodiabetic effects of statins by using a combined therapy could be expected.

\section{Abbreviations}

ACSIS: Acute Coronary Syndrome Israeli Surveys; BIP: Bezafibrate Infarction Prvention study; BMI: body mass index; FFAs: free fatty acids; HDL-C: high density lipoprotein- cholesterol; LDL-C: low density lipoprotein- cholesterol; MACE: major acute coronary event; MI: myocardial infarction; PPAR: peroxisome proliferator-activated receptor; T2DM: type 2 diabetes mellitus.

\section{Competing interests}

AT received speaker fee and travel expenses support from Abbott, Tribute, Novartis and Merck.

EZF declares that he has no competing interests.

\section{Authors' contribution}

Both authors have equally contributed in the conception and drafting of the manuscript. Both authors read and approved the final manuscript.

\section{Acknowledgments}

This work was supported in part by the Cardiovascular Diabetology Research Foundation (RA 58-040-684-1), Holon, Israel.

\section{Author details}

${ }^{1}$ Cardiac Rehabilitation Institute, Sheba Medical Center, 52621, Tel-Hashomer, Israel. '2Sackler Faculty of Medicine, Tel-Aviv University, 69978, Tel-Aviv, Israel. ${ }^{3}$ Cardiovascular Diabetology Research Foundation, 58484, Holon, Israel.

Received: 28 October 2012 Accepted: 31 October 2012

Published: 14 November 2012

\section{References}

1. Willson TM, Brown PJ, Sternbach DD, Henke BR: The PPARs: from orphan receptors to drug discovery. J Med Chem 2000, 43:527-550.

2. Tenenbaum A, Motro M, Fisman EZ: Dual and pan-peroxisome proliferator-activated receptors (PPAR) co-agonism: the bezafibrate lessons. Cardiovasc Diabetol 2005, 4:14.

3. Peters JM, Aoyama T, Burns AM, Gonzalez FJ: Bezafibrate is a dual ligand for PPARalpha and PPARbeta: studies using null mice. Biochim Biophys Acta 2003, 1632:80-89.

4. Poirier $\mathrm{H}$, Niot I, Monnot MC, Braissant $\mathrm{O}$, Meunier-Durmort C, Costet $\mathrm{P}$, Pineau T, Wahli W, Willson TM, Besnard P: Differential involvement of peroxisome-proliferator-activated receptors alpha and delta in fibrate and fatty-acid-mediated inductions of the gene encoding liver fattyacid-binding protein in the liver and the small intestine. Biochem J 2001, 355:481-488.

5. Berger J, Moller DE: The mechanisms of action of PPARs. Annu Rev Med 2002, 53:409-435.

6. Tenenbaum A, Fisman EZ, Motro M: Metabolic syndrome and type 2 diabetes mellitus: focus on peroxisome proliferator activated receptors (PPAR). Cardiovasc Diabetol 2003, 2:4.

7. Vamecq J, Latruffe N: Medical significance of peroxisome proliferatoractivated receptors. Lancet 1999, 354:141-148

8. Fruchart JC, Staels B, Duriez P: The role of fibric acids in atherosclerosis Curr Atheroscler Rep 2001, 3:83-92.

9. Brown JD, Plutzky J: Peroxisome proliferator-activated receptors as transcriptional nodal points and therapeutic targets. Circulation 2007, 115:518-533.

10. Friedland SN, Leong A, Filion KB, Genest J, Lega IC, Mottillo S, Poirier P, Reoch J, Eisenberg MJ: The cardiovascular effects of peroxisome proliferator-activated receptor agonists. Am J Med 2012, 125:126-33.
11. Berger JP, Akiyama TE, Meinke PT: PPARs: therapeutic targets for metabolic disease. Trends Pharmacol Sci 2005, 26:244-251.

12. Evans RM, Barish GD, Wang YX: PPARs and the complex journey to obesity. Nat Med 2004, 10:355-361.

13. Wang YX, Lee CH, Tiep S, Yu RT, Ham J, Kang H, Evans RM: Peroxisome-proliferator-activated receptor delta activates fat metabolism to prevent obesity. Cell 2003, 113:159-170.

14. Wang YX, Zhang CL, Yu RT, Cho HK, Nelson MC, Bayuga-Ocampo CR, Ham J, Kang H, Evans RM: Regulation of muscle fiber type and running endurance by PPAR delta. PLoS Biol 2004, 2:e294.

15. Dressel U, Allen TL, Pippal JB, Rohde PR, Lau P, Muscat GE: The peroxisome proliferator-activated receptor beta/delta agonist, GW501516, regulates the expression of genes involved in lipid catabolism and energy uncoupling in skeletal muscle cells. Mol Endocrinol 2003, 17:2477-2493.

16. Tenenbaum A, Motro M, Fisman EZ, Tanne D, Boyko V, Behar S: Bezafibrate for the secondary prevention of myocardial infarction in patients with metabolic syndrome. Arch Intern Med 2005, 165:1154-1160.

17. Coll T, Rodrïguez-Calvo R, Barroso E, Serrano L, Eyre E, Palomer X, VázquezCarrera M: Peroxisome proliferator-activated receptor (PPAR) beta/delta: a new potential therapeutic target for the treatment of metabolic syndrome. Curr Mol Pharmacol 2009, 2:46-55.

18. Wagner KD, Wagner N: Peroxisome proliferator-activated receptor beta/delta (PPARbeta/delta) acts as regulator of metabolism linked to multiple cellular functions. Pharmacol Ther 2010, 125:423-435.

19. Tenenbaum A, Fisman EZ: Fibrates are an essential part of modern anti-dyslipidemic arsenal: spotlight on atherogenic dyslipidemia and residual risk reduction. Cardiovasc Diabetol 2012, 11:125.

20. The BIP Study Group: Secondary prevention by raising HDL cholesterol and reducing triglycerides in patients with coronary artery disease: the Bezafibrate Infarction Prevention (BIP) study. Circulation 2000 102:21-27.

21. Meade T, Zuhrie R, Cook C, Cooper J: Bezafibrate in men with lower extremity arterial disease: randomised controlled trial. BMJ 2002, 325 (7373):1139.

22. Ikewaki K, Noma K, Tohyama J, Kido T, Mochizuki S: Effects of bezafibrate on lipoprotein subclasses and inflammatory markers in patients with hypertriglyceridemia-a nuclear magnetic resonance study. Int J Cardiol 2005, 101:441-447.

23. Ayaori M, Momiyama Y, Fayad ZA, Yonemura A, Ohmori R, Kihara T, Tanaka N, Nakaya K, Ogura M, Sawada S, Taniguchi H, Kusuhara M, Nagata M, Nakamura H, Ohsuzu F: Effect of bezafibrate therapy on atherosclerotic aortic plaques detected by MRI in dyslipidemic patients with hypertriglyceridemia. Atherosclerosis 2008, 196:425-433.

24. Benderly M, Graff E, Reicher-Reiss H, Behar S, Brunner D, Goldbourt U: Fibrinogen is a predictor of mortality in coronary heart disease patients. The Bezafibrate Infarction Prevention (BIP) Study Group. Arterioscler Thromb Vasc Biol 1996, 16:351-356.

25. Jonkers IJ, Mohrschladt MF, Westendorp RG, van der Laarse A, Smelt AH: Severe hypertriglyceridemia with insulin resistance is associated with systemic inflammation: reversal with bezafibrate therapy in a randomized controlled trial. Am J Med 2002, 112:275-280.

26. Madrid-Miller A, Moreno-Ruiz LA, Borrayo-Sánchez G, Almeida-Gutiérrez E, Martínez-Gómez DF, Jáuregui-Aguilar R: Impact of bezafibrate treatment in patients with hyperfibrinogenemia and ST-elevation acute myocardial infarction: a randomized clinical trial. Cir Cir 2010, 78:229-237.

27. Krysiak R, Gdula-Dymek A, Okopien B: The effect of bezafibrate and omega-3 fatty acids on lymphocyte cytokine release and systemic inflammation in patients with isolated hypertriglyceridemia. Eur J Clin Pharmacol 2011, 67:1109-1117.

28. Nyström T, Bratt G, Sjöholm A: Bezafibrate-induced improvement in glucose uptake and endothelial function in protease inhibitor-associated insulin resistance. J Intern Med 2002, 252:570-574.

29. Seiler C, Suter TM, Hess OM: Exercise-induced vasomotion of angiographically normal and stenotic coronary arteries improves after cholesterol-lowering drug therapy with bezafibrate. J Am Coll Cardiol 1995, 26:1615-1622.

30. Meco JF, Vila R, Pujol R, Bros R, Domènech P, Fiol C, Pintó X: Improvement in endothelial dysfunction in patients with hypoalphalipoproteinemia and coronary artery disease treated with bezafibrate. J Cardiovasc Pharmacol 2001, 38:250-258. 
31. Hanefeld C, Bulut-Streich N, Bulut D, Graf C, Mügge A, Spiecker M: Comparison of endothelial function in patients with metabolic syndrome on bezafibrate or atorvastatin therapy. Cardiovasc Drugs Ther 2005, 19:153-155.

32. Goldenberg I, Benderly M, Goldbourt U, BIP Study Group: Secondary prevention with bezafibrate therapy for the treatment of dyslipidemia: an extended follow-up of the BIP trial. J Am Coll Cardiol 2008, 51:459-465.

33. Sano K, Nakamura T, Hirano M, Kitta Y, Kobayashi T, Fujioka D, Saito Y, Yano T, Watanabe K, Watanabe Y, Mishina H, Obata JE, Kawabata K, Kugiyama K: Comparative study of bezafibrate and pravastatin in patients with coronary artery disease and high levels of remnant lipoprotein. Circ $J$ 2010, 74:1644-1650.

34. Tenenbaum A, Fisman EZ: "The metabolic syndrome. . . is dead": these reports are an exaggeration. Cardiovasc Diabetol 2011, 10:11

35. Ericsson CG, Nilsson J, Grip L, Svane B, Hamsten A: Effect of bezafibrate treatment over five years on coronary plaques causing 20\% to $50 \%$ diameter narrowing (The Bezafibrate Coronary Atherosclerosis Intervention Trial [BECAIT]). Am J Cardiol 1997, 80:1125-1129.

36. Elkeles RS, Diamond JR, Poulter C, Dhanjil S, Nicolaides AN, Mahmood S, Richmond W, Mather H, Sharp P, Feher MD: Cardiovascular outcomes in type 2 diabetes. A double-blind placebo-controlled study of bezafibrate: the St. Mary's, Ealing, Northwick Park Diabetes Cardiovascular Disease Prevention (SENDCAP) Study. Diabetes Care 1998, 21:641-648.

37. Jun M, Foote C, LV J, Neal B, Patel A, Nicholls SJ, Grobbee DE, Cass A, Chalmers J, Perkovic V: Effects of fibrates on cardiovascular outcomes: a systematic review and meta-analysis. Lancet 2010, 375:1875-1878.

38. Taniguchi A, Fukushima M, Sakai M, Tokuyama K, Nagata I, Fukunaga A, Kishimoto H, Doi K, Yamashita Y, Matsuura T, Kitatani N, Okumura T, Nagasaka S, Nakaishi S, Nakai Y: Effects of bezafibrate on insulin sensitivity and insulin secretion in non-obese Japanese type 2 diabetic patients. Metabolism 2001, 50:477-480

39. Kim Jl, Tsujino T, Fujioka Y, Saito K, Yokoyama M: Bezafibrate improves hypertension and insulin sensitivity in humans. Hypertens Res 2003, 26:307-313.

40. Tenenbaum A, Fisman EZ, Boyko V, Benderly M, Tanne D, Haim M, Matas Z, Motro M, Behar S: Attenuation of progression of insulin resistance in patients with coronary artery disease by bezafibrate. Arch Intern Med 2006, 166:737-741

41. Ogawa S, Takeuchi K, Sugimura K, Fukuda M, Lee R, Ito S, Sato T: Bezafibrate reduces blood glucose in type 2 diabetes mellitus. Metabolism 2000, 49:331-334.

42. Tenenbaum H, Behar S, Boyko V, Adler Y, Fisman EZ, Tanne D, Lapidot M, Schwammenthal E, Feinberg M, Matas Z, Motro M, Tenenbaum A: Long-term effect of bezafibrate on pancreatic betacell function and insulin resistance in patients with diabetes. Atherosclerosis 2007, 194:265-271.

43. Teramoto T, Shirai K, Daida H, Yamada N: Effects of bezafibrate on lipid and glucose metabolism in dyslipidemic patients with diabetes: the J-BENEFIT study. Cardiovasc Diabetol 2012, 11:29.

44. Tenenbaum A, Motro M, Fisman EZ, Schwammenthal E, Adler $Y$, Goldenberg I, Leor J, Boyko V, Mandelzweig L, Behar S: Peroxisome proliferator-activated receptors ligand bezafibrate for prevention of type 2 diabetes mellitus in patients with coronary artery disease. Circulation 2004, 109:2197-2202.

45. Tenenbaum A, Motro M, Fisman EZ, Adler Y, Shemesh J, Tanne D, Leor J, Boyko V, Schwammenthal E, Behar S: Effect of bezafibrate on incidence of type 2 diabetes mellitus in obese patients. Eur Heart $J$ 2005, 26:2032-2038

46. Flory JH, Ellenberg S, Szapary PO, Strom BL, Hennessy S: Antidiabetic action of bezafibrate in a large observational database. Diabetes Care 2009, 32:547-551.

47. Shimabukuro M, Zhou YT, Levi M, Unger RH: Fatty acid-induced beta cell apoptosis: a link between obesity and diabetes. Proc Natl Acad Sci USA 1998, 95:2498-2502

48. Sugden MC, Holness MJ: Potential role of peroxisome proliferatoractivated receptor-alpha in the modulation of glucose-stimulated insulin secretion. Diabetes 2004, 53(Suppl 1):S71-S81.

49. Unger RH: Lipotoxicity in the pathogenesis of obesity-dependent NIDDM. Genetic and clinical implications. Diabetes 1995, 44:863-870.
50. Robertson RP, Harmon J, Tran PO, Poitout V: Beta-cell glucose toxicity, lipotoxicity, and chronic oxidative stress in type 2 diabetes. Diabetes 2004, 53(Suppl 1):S119-S124.

51. Haber EP, Procopio J, Carvalho CR, Carpinelli AR, Newsholme P, Curi R: New insights into fatty acid modulation of pancreatic beta-cell function. Int Rev Cytol 2006, 248:1-41

52. Hansen BC, Tigno XT, Bénardeau A, Meyer M, Sebokova E, Mizrahi J: Effects of aleglitazar, a balanced dual peroxisome proliferator-activated receptor $a / \gamma$ agonist on glycemic and lipid parameters in a primate model of the metabolic syndrome. Cardiovasc Diabetol 2011, 10:7.

53. Cavaghan MK, Ehrmann DA, Polonsky KS: Interactions between insulin resistance and insulin secretion in the development of glucose intolerance. J Clin Invest 2000, 106:329-333.

54. Mathew M, Tay E, Cusi K: Elevated plasma free fatty acids increase cardiovascular risk by inducing plasma biomarkers of endothelial activation, myeloperoxidase and PAI-1 in healthy subjects. CardiovasC Diabetol 2010, 9:9.

55. Pick A, Clark J, Kubstrup C, Levisetti M, Pugh W, Bonner-Weir S, Polonsky KS: Role of apoptosis in failure of beta cell mass compensation for insulin resistance and beta cell defects in the male Zucker diabetic fatty rat. Diabetes 1998, 47:358-364.

56. El-Assaad W, Buteau J, Peyot ML, Nolan C, Roduit R, Hardy S, Joly E, Dbaibo G, Rosenberg L, Prentki M: Saturated fatty acids synergize with elevated glucose to cause pancreatic beta-cell death. Endocrinology 2003, 144:4154-4163.

57. Hiuge A, Tenenbaum A, Maeda N, Benderly M, Kumada M, Fisman EZ, Tanne D, Matas Z, Hibuse T, Fujita K, Nishizawa H, Adler Y, Motro M, Kihara S, Shimomura I, Behar S, Funahashi T: Effects of peroxisome proliferatoractivated receptor ligands, bezafibrate and fenofibrate, on adiponectin level. Arterioscler Thromb Vasc Biol 2007, 27:635-641.

58. Cannon CP, Steinberg BA, Murphy SA, Mega JL, Braunwald E: Meta-analysis of cardiovascular outcomes trials comparing intensive versus moderate statin therapy. J Am Coll Cardiol 2006, 48:438-445

59. Westerink J, Visseren F: Pharmacological and non-pharmacological interventions to influence adipose tissue function. Cardiovasc Diabetol 2011, 10:13.

60. Jukema JW, Cannon CP, de Craen AJ, Westendorp RG, Trompet S: The controversies of statin therapy: weighing the evidence. J Am Coll Cardiol 2012, 60:875-881.

61. An $X, Y u$ D, Zhang $R$, Zhu J, Du R, Shi Y, Xiong $X$ : Insulin resistance predicts progression of de novo atherosclerotic plaques in patients with coronary heart disease: a one-year follow-up study. Cardiovasc Diabetol 2012, 11:71.

62. Tenenbaum A, Fisman EZ, Motro M, Adler Y: Optimal management of combined dyslipidemia: what have we behind statins monotherapy? Adv Cardiol 2008, 45:127-153.

63. Sacks FM, Tonkin AM, Shepherd J, Braunwald E, Cobbe S, Hawkins CM Keech A, Packard C, Simes J, Byington R, Furberg CD, for the Prospective Pravastatin Pooling Project: Effect of pravastatin on coronary disease events in subgroups defined by coronary risk factors. Circulation 2000, 102:1893-1900.

64. Daida H, Takayama T, Hiro T, Yamagishi M, Hirayama A, Saito S, Yamaguchi T, Matsuzaki M, for the COSMOS Investigators: High $\mathrm{HbA} 1 \mathrm{c}$ levels correlate with reduced plaque regression during statin treatment in patients with stable coronary artery disease: Results of the coronary atherosclerosis study measuring effects of rosuvastatin using intravascular ultrasound in Japanese subjects (COSMOS). Cardiovasc Diabetol 2012, 11:87.

65. Ballantyne CM, Herd JA, Ferlic LL, Dunn JK, Farmer JA, Jones PH, Schein JR, Gotto AM Jr: Influence of low HDL on progression of coronary artery disease and response to fluvastatin therapy. Circulation 1999, 99:736-743.

66. Hermans MP, Sacks FM, Ahn SA, Rousseau MF: Non-HDL-cholesterol as valid surrogate to apolipoprotein B100 measurement in diabetes: Discriminant Ratio and unbiased equivalence. Cardiovasc Diabetol 2011, 10:20.

67. Hermans MP, Ahn SA, Rousseau MF: $\log (\mathrm{TG}) / \mathrm{HDL}-\mathrm{C}$ is related to both residual cardiometabolic risk and $\beta$-cell function loss in type 2 diabetes males. Cardiovasc Diabetol 2010, 9:88.

68. Pfeffer MA, Sacks FM, Moyé LA, East C, Goldman S, Nash DT, Rouleau JR, Rouleau JL, Sussex BA, Theroux P, Vanden Belt RJ, Braunwald E: Influence of baseline lipids on effectiveness of pravastatin in the CARE trial. J Am Coll Cardiol 1999, 33:125-130. 
69. Verhagen SN, Wassink AM, van der Graaf Y, Gorter PM, Visseren FL, SMART Study Group: Insulin resistance increases the occurrence of new cardiovascular events in patients with manifest arterial disease without known diabetes. the SMART study. Cardiovasc Diabetol 2011, 10:100.

70. Chapman MJ, Redfern JS, MCGovern ME, Giral P: Optimal pharmacotherapy to combat the atherogenic lipid triad. Curr Opin Cardiol 2011, 26:403-411.

71. Toth PP, Simko RJ, Palli SR, Koselleck D, Quimbo RA, Cziraky MJ: The impact of serum lipids on risk for microangiopathy in patients with type 2 diabetes mellitus. Cardiovasc Diabetol 2012, 11:109.

72. Sukhija R, Prayaga S, Marashdeh M, Bursac Z, Kakar P, Bansal D, Sachdeva R, Kesan SH, Mehta JL: Effect of statins on fasting plasma glucose in diabetic and nondiabetic patients. J Investig Med 2009, 57:495-499.

73. Coleman $\mathrm{Cl}$, Reinhart K, Kluger J, White CM: The effect of statins on the development of new-onset type 2 diabetes: a meta-analysis of randomized controlled trials. Curr Med Res Opin 2006, 24:1359-1362.

74. Sattar N, Preiss D, Murray HM, Welsh P, Buckley BM, de Craen AJ, Seshasai SR, McMurray JJ, Freeman DJ, Jukema JW, Macfarlane PW, Packard CJ, Stott DJ, Westendorp RG, Shepherd J, Davis BR, Pressel SL, Marchioli R, Marfisi RM, Maggioni AP, Tavazzi L, Tognoni G, Kjekshus J, Pedersen TR, Cook TJ, Gotto AM, Clearfield MB, Downs JR, Nakamura H, Ohashi Y, et al: Statins and risk of incident diabetes: a collaborative meta-analysis of randomized statin trials. Lancet 2010, 375:735-742.

75. Rajpathak SN, Kumbhani DJ, Crandall J, Barzilai N, Alderman M, Ridker PM: Statin therapy and risk of developing type 2 diabetes: a meta-analysis. Diabetes Care 2009, 32:1924-1929.

76. Preiss D, Seshasai SR, Welsh P, Murphy SA, Ho JE, Waters DD, DeMicco DA, Barter P, Cannon CP, Sabatine MS, Braunwald E, Kastelein JJ, de Lemos JA, Blazing MA, Pedersen TR, Tikkanen MJ, Sattar N, Ray KK: Risk of incident diabetes with intensive-dose compared with moderate-dose statin therapy: a meta-analysis. JAMA 2011, 305:2556-2564.

77. Kjekshus J, Apetrei E, Barrios V, Böhm M, Cleland JG, Cornel JH, Dunselman P, Fonseca C, Goudev A, Grande P, Gullestad L, Hjalmarson A, Hradec J, Jánosi A, Kamenský G, Komajda M, Korewicki J, Kuusi T, Mach F, Mareev V, McMurray JJ, Ranjith N, Schaufelberger M, Vanhaecke J, van Veldhuisen DJ, Waagstein F, Wedel H, Wikstrand J, CORONA Group: Rosuvastatin in older patients with systolic heart failure. N Engl J Med 2007, 357:2248-2261.

78. Ridker PM, Danielson E, Fonseca FA, Genest J, Gotto AM Jr, Kastelein JJ, Koenig W, Libby P, Lorenzatti AJ, MacFadyen JG, Nordestgaard BG, Shepherd J, Willerson JT, Glynn RJ, JUPITER Study Group: Rosuvastatin to prevent vascular events in men and women with elevated C-reactive protein. N Engl J Med 2008, 359:2195-2207.

79. Zaharan NL, Williams D, Bennett K: Statins and Risk of Treated Incident Diabetes in a Primary Care Population. Br J Clin Pharmacol 2012, doi:10.1111/j.1365-2125.2012.04403.x.

80. Rautio N, Jokelainen J, Oksa H, Saaristo T, Peltonen M, Vanhala M, Puolijoki $H$, Moilanen L, Tuomilehto J, Keinänen-Kiukaanniemi S, Uusitupa M: Do statins interfere with lifestyle intervention in the prevention of diabetes in primary healthcare? One-year follow-up of the FIN-D2D project. BMJ Open 2012, 2(5):pii: e001472.

81. Waters DD, Ho JE, DeMicco DA, Breazna A, Arsenault BJ, Wun CC, Kastelein $J$, Colhoun H, Barter P: Predictors of new-onset diabetes in patients treated with atorvastatin: results from 3 large randomized clinical trials. J Am Coll Cardiol 2011, 57:1535-1545.

82. Preiss D, Sattar N: Statins and the risk of new-onset diabetes: a review of recent evidence. Curr Opin Lipidol 2011, 22:460-466.

83. Scandinavian Simvastatin Survival Study Study Group: Randomised trial of cholesterol lowering in 4444 patients with coronary heart disease: the Scandinavian Simvastatin Survival Study (4S). Lancet 1994, 344:1383-1389.

84. Teramoto T: Pitavastatin: clinical effects from the LIVES Study. Atheroscler 2011, 12:285-288.

85. Tenenbaum A, Fisman EZ: "If it ain't broke, don't fix it": a commentary on the positive-negative results of the ACCORD Lipid study. CardiovasC Diabetol 2010, 9:24.

86. Beggs PW, Clark DW, Williams SM, Coulter DM: A comparison of the use, effectiveness and safety of bezafibrate, gemfibrozil and simvastatin in normal clinical practice using the New Zealand Intensive Medicines Monitoring Programme (IMMP). Br J Clin Pharmacol 1999, 47:99-104.

87. Fruchart JC, Sacks F, Hermans MP, Assmann G, Brown WV, Ceska R, Chapman MJ, Dodson PM, Fioretto P, Ginsberg HN, Kadowaki T, Lablanche JM, Marx N, Plutzky J, Reiner Z, Rosenson RS, Staels B, Stock JK, Sy R, Wanner C, Zambon A, Zimmet P: The Residual Risk Reduction Initiative: a call to action to reduce residual vascular risk in patients with dyslipidemia. Am J Cardiol 2008, 102:1K-34K

88. Farnier M: Combination Therapy with an HMG-CoA Reductase Inhibitor and a Fibric Acid Derivative: A Critical Review of Potential Benefits and Drawbacks. Am J Cardiovasc Drugs 2003, 3:169-178.

89. Shek A, Ferrill MJ: Statin-fibrate combination therapy. Ann Pharmacother 2001, 35:908-917.

90. Prueksaritanont T, Tang C, Qui Y, Mu L, Subramanian R, Lin JH: Effects of fibrates on metabolism of statins in human hepatocytes. Drug Metab Dispos 2002, 30:1280-1287.

91. Backman JT, Kyrklund C, Kivistö KT, Wang JS, Neuvonen PJ: Plasma concentrations of active simvastatin acid are increased by gemfibrozil. Clin Pharmacol Ther 2000, 68:122-129.

92. Kyrklund C, Backman JT, Kivistö KT, Neuvonen M, Laitila J, Neuvonen PJ: Plasma conentrations of active lovastatin acid are markedly increased by gemfibrozil but not by bezafibrate. Clin Pharmacol Ther 2001, 69:340-345.

93. Kehely A, MacMahon M, Barbir M, Wray R, Hunt BJ, Prescott RJ, Thompson GR: Combined bezafibrate and simvastatin treatment for mixed hyperlipidaemia. QJM 1995, 88:421-427.

94. Gavish D, Leibovitz E, Shapira I, Rubinstein A: Bezafibrate and simvastatin combination therapy for diabetic dyslipidaemia: efficacy and safety. J Intern Med 2000, 247:563-569.

95. Pauciullo P, Borgnino C, Paoletti R, Mariani M, Mancini M: Efficacy and safety of a combination of fluvastatin and bezafibrate in patients with mixed hyperlipidaemia (FACT study). Atherosclerosis 2000, 150:429-436.

96. Farnier M, Salko T, Isaacsohn JL, Troendle AJ, Dejager S, Gonasun L: Effects of baseline level of triglycerides on changes in lipid levels from combined fluvastatin + fibrate (bezafibrate, fenofibrate, or gemfibrozil). Am J Cardiol 2003, 92:794-797.

97. Tenenbaum A, Medvedofsky D, Fisman EZ, Bubyr L, Matetzky S, Tanne D, Klempfner R, Shemesh J, Goldenberg I: Cardiovascular events in patients received combined fibrate/statin treatment versus statin monotherapy: Acute Coronary Syndrome Israeli Surveys data. PLoS One 2012, 7(4): e35298.

doi: $10.1186 / 1475-2840-11-140$

Cite this article as: Tenenbaum and Fisman: Balanced pan-PPAR activator bezafibrate in combination with statin: comprehensive lipids control and diabetes prevention?. Cardiovascular Diabetology 2012 11:140.

\section{Submit your next manuscript to BioMed Central and take full advantage of:}

- Convenient online submission

- Thorough peer review

- No space constraints or color figure charges

- Immediate publication on acceptance

- Inclusion in PubMed, CAS, Scopus and Google Scholar

- Research which is freely available for redistribution

Submit your manuscript at www.biomedcentral.com/submit
C) Biomed Central 